\title{
Regional Variation in Juice Quality Characteristics of Four Cider Apple (Malus $\times$ domestica Borkh.) Cultivars in Northwest and Central Washington
}

\author{
Travis Robert Alexander ${ }^{1}$, Jacqueline King, Andrew Zimmerman, \\ and Carol A. Miles \\ Department of Horticulture, Washington State University Northwestern \\ Washington Research and Extension Center, 16650 State Route 536, \\ Mount Vernon, WA 98273
}

Additional index words. bittersharp, bittersweet, 'Brown Snout', Dabinett', 'Kingston Black', 'Yarlington Mill', acid, tannin

\begin{abstract}
In this study, four cider apple (Malus $\times$ domestica) cultivars, Brown Snout, Dabinett, Kingston Black, and Yarlington Mill, were collected from four orchards, two in northwest Washington and two in central Washington, to compare juice quality characteristics. Northwest Washington has a cool, humid summer climate $\left(16.0^{\circ} \mathrm{C}\right.$ on average during this study) and is the origin of the state's cider apple industry, while central Washington has a hot, dry summer climate $\left(22.1{ }^{\circ} \mathrm{C}\right.$ on average during this study) and is the center of the state's dessert apple industry. Each year from 2012 to 2015, fruit of the four cultivars were harvested and stored at each orchard until they were collected. Fruit were pressed and the juice analyzed for five quality characteristics important to cider making: soluble solids concentration [SSC (\%)], specific gravity (SG), pH, titratable acidity [TA, malic acid equivalent $\left(\mathrm{g} \cdot \mathrm{L}^{-1}\right)$ ], and tannin [tannic acid equivalent (\%)]. Harvest dates and climate data were recorded annually for each orchard location. There were no significant differences in any of the juice quality characteristics due to region and no significant interaction of region, cultivar, and/or year. Results did show, as expected, a significant difference in all five juice characteristics due to cultivar. 'Brown Snout', 'Dabinett', and 'Kingston Black' were higher in SSC and SG than 'Yarlington Mill'; 'Dabinett' had the highest pH and lowest TA while 'Kingston Black' had the lowest pH and highest TA; and tannin was highest in 'Yarlington Mill' and lowest in 'Kingston Black'. There was also a difference in SG and tannin due to year; SG was lowest in 2013 while tannin was highest in 2012. The difference in SG from year to year may be a result of variable year-to-year storage time at each orchard before collection of fruit. The difference in tannin from year to year was likely due to climatic variation over the four years of this study. On average, growing degree days (GDD) increased $10 \%$ and chilling hours $(\mathrm{CH})$ decreased $10 \%$ from 2012 to 2015 in both regions. Classification of the four cultivars included in this study differed from historical records at the Long Ashton Research Station (LARS) in England; in the current study, the four cultivars exhibited tannin levels below $0.20 \%$ and would not be classified as bitter, unlike their historical classification at LARS. Results from this study indicate that variations in juice quality characteristics occur between cultivars as expected and occur within a cultivar from year-to-year, but for the four cultivars included in this study variations did not occur due to production region in Washington.
\end{abstract}

Cider is fermented apple (Malus $\times$ domestica Borkh.) juice, and is often referred to as hard cider in the United States in contrast to the nonfermented, unfiltered apple juice that is referred to as fresh cider or sweet cider (Khanizadeh et al., 2000; Trowbridge, 1917). Cider may vary in alcohol content from

Received for publication 21 July 2016. Accepted for publication 8 Sept. 2016.

We gratefully acknowledge the financial support provided by the Washington State Department of Agriculture, Washington State University Center for Sustaining Agriculture and Natural Resources, Northwest Agricultural Research Foundation, Northwest Cider Association, and State project WN00427-Acc. no.1000194.

${ }^{1}$ Corresponding author. E-mail: travis.alexander@ wsu.edu. less than $1.2 \%$ alcohol by volume (ABV) as found in French cidre doux, to $8.5 \% \mathrm{ABV}$ in traditional English ciders (Lea, 2008). In the United States, current federal law defines cider by an $\mathrm{ABV}$ of less than $8.5 \%$; anything above this ABV may still be considered a cider but is taxed at a higher wine or champagne rate depending on percent $\mathrm{ABV}$ and carbonation levels [Alcohol and Tobacco Tax and Trade Bureau (TTB), 2015]. Although cider only accounts for $1 \%$ of the alcoholic beverage market in the United States, it is the fastest growing segment with a 22 -fold increase in production from 2007 to 2015 (TTB, 2016). In 2007, 2.9 million liters of cider were produced in the United States, increasing to 65 million liters in 2015 (TTB, 2016). The volume of cider produced in Washington grew 25-fold from 2007 to 2015 , from 168,000 to 4 million liters, and accounted for $6 \%$ of the total U.S. cider production in 2015 (TTB, 2016). The number of cideries in Washington increased more than 5fold in the last 9 years, from less than 10 cideries in 2007 to 56 reported cideries in 2015 (Northwest Cider Association, 2015; The Cyder Market, 2015).

Quality cider is traditionally made from bittersweet (acid $<0.45 \%$, tannin $>0.20 \%$ ) and bittersharp (acid $>0.45 \%$, tannin $>0.20 \%$ ) cider apples (Barker and Burroughs, 1953). Growers have historically selected cider apple cultivars for their fruit acid and tannin content levels (Alwood, 1903; Barker, 1911; Buell, 1869; Trowbridge, 1917). As the supply of cider apples is heavily outweighed by demand, dessert apple juice often forms the base of both craft and industrial ciders as it tends to be more readily available and relatively inexpensive (Merwin et al., 2008; Moulton et al., 2010). Craft cider makers usually achieve their desired levels of bitterness and sharpness by blending in bittersweet, bittersharp, and crab apple cultivars, whereas industrial cider makers add exogenous malic acid and tannin (Khanizadeh et al., 2000; Lea, 2008; Merwin et al., 2008; Pollard, 1953). For product consistency, cider makers should chemically analyze their juice throughout production (M. Roberts, personal communication). The ability to create a consistent product is critical in an industry where juice supply varies from year to year both in quantity and characteristics.

Chemical analysis of cider juice generally includes an assessment of SSC (\%), SG, $\mathrm{pH}$, TA [malic acid equivalent $\left.\left(\mathrm{g} \cdot \mathrm{L}^{-1}\right)\right]$, and tannin [tannic acid equivalent (\%)]. SSC and $\mathrm{SG}$ can be measured with a refractometer, which measures the refractive index of a solution, or a hydrometer, which measures the relative density of a solution to a reference (usually pure water), assuming proper calibration of each instrument. A refractometer is generally used prefermentation as ethanol significantly alters the refractive index, whereas a hydrometer is used throughout fermentation with decreasing accuracy toward the end of fermentation as increasing ethanol alters the density of the solution (often providing for a negative sugar concentration). Prefermentation measures of both SSC and SG are used to predict alcohol content postfermentation and accordingly aide the cider maker in deciding if exogenous sugar should be added or if juices with higher sugar content should be blended (Moulton et al., 2010). pH can be measured with a $\mathrm{pH}$ meter or $\mathrm{pH}$ indicator paper, the choice depending on the cider maker's preference for accuracy. TA can be measured by titration with a base using $\mathrm{pH}$ indicator paper or a $\mathrm{pH}$ meter to reach the targeted endpoint, again the choice regarding the method for monitoring $\mathrm{pH}$ is based on preference for accuracy. Cider makers target a $\mathrm{pH}$ range of 3.3-3.7 and a TA range of $1.0-15.0 \mathrm{~g} \cdot \mathrm{L}^{-1}$ malic acid (Mitchell, 2015). For $\mathrm{pH}$, the targeted range is based on optimal yeast fermentation conditions, and for TA, the targeted range is based on desired final product flavor, specifically 
sharpness. Tannin is traditionally measured by titration with potassium permanganate and indigo carmine indicator (Lowenthal, 1877). Tannin also contributes to final product flavor, specifically the astringency and mouthfeel of the cider.

Planting site has a significant impact on apple fruit quality; for example Miller et al. (2005) found an inconsistent interaction between site and cultivar for more than one juice quality characteristic. Specifically, the authors found that SSC and TA were significantly higher for apple cultivars Golden Delicious and Gala Supreme than for cultivars Fuji and Enterprise across 14 planting sites in North America. However, fruit weight and TA were found to be significantly higher for all four cultivars at the British Columbia planting site than at the southern West Virginia planting site. These differences in weight and acidity were attributed to the climatic differences of the planting sites, specifically the duration, temperature, and light intensity of the growing seasons at each site. The authors concluded that "no single cultivar developed superior qualities across all sites; likewise no one site consistently produced apple cultivars with the most superior quality." While strong correlations have been established between fruit quality and environmental factors, such as light intensity and distribution within a canopy, and have been shown to affect apple fruit SSC and firmness (Robinson et al., 1983), fruit quality is too dynamic for growers to make regional assumptions (Grappadelli, 2003). Cider apples have historically been grown in maritime climates like that of England, France, and northwest Washington, but the suitability of continental climates like that of central Washington is unknown. This study is important because growers are planting the same handful of European cultivars in a diversity of climates across the United States, and cider makers are expecting these cultivars to produce juice characteristics that may not be consistent with what is actually attained in their region. By examining the regional differences, if any, in the juice quality characteristics of four popular cider apple cultivars grown at four different sites where cider apples are commonly grown in northwest and central Washington, this study will allow for growers and cider makers in
Washington State to make appropriate purchasing and planting decisions for their region.

\section{Materials and methods}

Cider apple orchards. This study included four orchards, with two orchards located in northwest Washington, Alpenfire Cider and Washington State University Northwestern Washington Research and Extension Center (WSU NWREC), and two orchards located in central Washington, Snowdrift Cider Co. and Tieton Cider Works. Alpenfire Cider is located in Port Townsend $\left(48^{\circ} 4^{\prime} 57^{\prime \prime}, 122^{\circ} 52^{\prime} 34^{\prime \prime}\right)$ with a Tukey gravelly loam soil (isotic, mesic Vitrandic Haploxerepts; U.S. Department of Agriculture, 2013). The trees from which apples were harvested were grafted on dwarfing 'M.9' rootstock, supported by trellis, and managed to a tall spindle architecture. WSU NWREC is located in Mount Vernon $\left(48^{\circ} 26^{\prime} 21^{\prime \prime}, 122^{\circ} 23^{\prime} 15^{\prime \prime}\right)$ with a Skagit silt loam soil (mixed, superactive, nonacid, mesic Fluvaquentic Endoaquepts). The trees from which apples were harvested were grafted on semidwarfing 'M.M.106' rootstock, freestanding, and managed to a central leader architecture. Snowdrift Cider Co. is located in East Wenatchee $\left(47^{\circ} 24^{\prime} 2.1^{\prime \prime}, 120^{\circ} 10^{\prime} 43^{\prime \prime}\right)$ with Magallon fine sandy loam soil (mixed, mesic Aridic Haploxerolls). The trees from which apples were harvested were grafted on semistandard 'M.M.111' rootstock, freestanding, and managed to a modified central leader. Tieton Cider Works is located in Tieton $\left(46^{\circ} 36^{\prime} 57^{\prime \prime}, 120^{\circ} 31^{\prime} 18^{\prime \prime}\right)$ with a Tieton loam soil (mixed, superactive, mesic Typic Argixerolls). The trees from which apples were harvested were grafted on dwarfing 'M.9-337' rootstock, supported by trellis, and managed to a tall spindle architecture. The two northwest Washington orchards have a cool, humid summer climate $\left(13.5{ }^{\circ} \mathrm{C}, 283 \mathrm{~mm}\right.$ precipitation, on average), and the region is noted as the origin of the state's cider apple industry, while the two central Washington orchards have a hot, dry summer climate $\left(15.9^{\circ} \mathrm{C}, 95 \mathrm{~mm}\right.$ precipitation, on average) and are in the center of the state's dessert apple industry. Long-term climate data for each orchard are summarized in Table 1 (Western Regional Climate Center, 2010).

Cider apple fruit harvest. At each site, fruit were harvested and stored following common practices for that orchard. For Alpenfire Cider, apples were harvested when seeds were black and fruit felt firm and/or had reached the desired threshold range of 11-14 ${ }^{\circ}$ Brix depending on cultivar and weather. For WSU NWREC, apples were harvested when seeds were black, flesh was in the 8-9 range on the 9-point $\mathrm{BC} /$ Ontario starch ripeness scale, and/or fruit had reached the desired threshold range of $11-14{ }^{\circ}$ Brix depending on cultivar and weather (Chu and Wilson, 2000; Lau, 1988). For Snowdrift Cider Co., apples were harvested when flesh surface area was greater than $60 \%$ free of starch $(\approx 8-9$ range on the $\mathrm{BC} /$ Ontario scale) and/or there was significant ground fall. For Tieton Cider Works, apples were harvested when seeds were black, fruit tasted sweet (subjective metric specific to the cider maker), and/or there was significant ground fall. Each year, one crate $(18 \mathrm{~kg}$ on average) of fruit randomly selected from multiple trees of each of the four cultivars was collected from the four orchards after harvest, a period ranging from October to November. Following common cider maker practice, fruit were simultaneously processed at WSU NWREC when collection from all four orchards was complete. Consequently, on average, fruit were cold stored (around $0{ }^{\circ} \mathrm{C}$ ) for up to 2 months during the time between harvest and pressing, and this may have had a substantial impact on SSC values among orchards.

Cider apple juice measurements. Each year when all samples were collected from all four sites, the fruit were milled (MultiMax 30; Zambelli Enotech, Camisano Vicentino, Italy) and pressed (Carezza; Enotecnica Pillan, Camisano Vicentino, Italy). The respective juice samples were collected in $500-\mathrm{mL}$ plastic bottles and stored at $-15{ }^{\circ} \mathrm{C}$ for 2 months. The frozen juice samples were thawed to $20^{\circ} \mathrm{C}$ and analyzed for five quality characteristics: $\operatorname{SSC}(\%)$, $\mathrm{SG}, \mathrm{pH}, \mathrm{TA}$ [malic acid equivalent $\left(\mathrm{g} \cdot \mathrm{L}^{-1}\right)$ ], and tannin [tannic acid equivalent (\%)]. SSC, $\mathrm{SG}, \mathrm{pH}$, TA, and tannin were measured as described by Miles and King (2014). The Lowenthal method of measuring tannin was used so that values obtained in the current study could be compared with historic values measured for each cultivar at the LARS in England (Lea, 2008; Williams, 1987).

Weather data acquisition. Temperature, GDD (base of $5.6^{\circ} \mathrm{C}$; 1 Jan. to 31 Oct.), and $\mathrm{CH}$ (base of $7.2^{\circ} \mathrm{C} ; 1$ Oct. to 31 May) were accessed for each orchard from WSU AgWeatherNet stations (AgWeatherNet, 2015). For the Alpenfire Cider site, the

Table 1. Long-term climate data (1891-2010) for two cider orchards in northwest Washington (Alpenfire Cider and WSU NWREC) and central Washington (Snowdrift Cider Co. and Tieton Cider Works), for the growing season (March-September) and the dormant season (October-February).

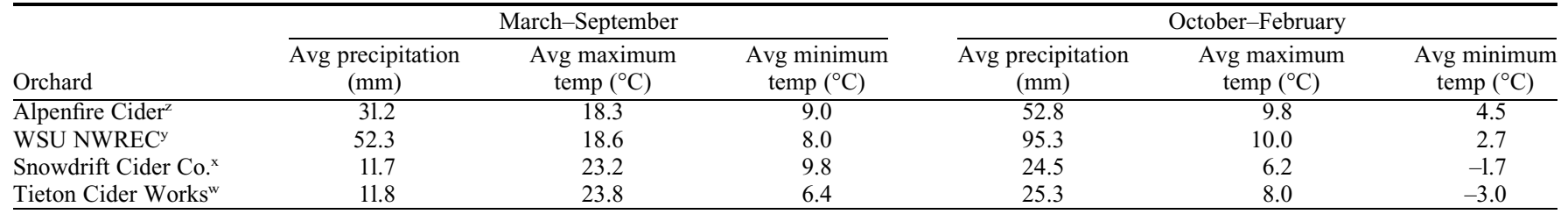

WSU NWREC = Washington State University Northwestern Washington Research and Extension Center.

${ }^{\mathrm{z}}$ Western Regional Climate Center COOP Station number 456678, Port Townsend.

${ }^{y}$ Western Regional Climate Center COOP Station number 455678, Mount Vernon.

${ }^{\mathrm{x}}$ Western Regional Climate Center COOP Station number 459082, Wenatchee Pangborn Airport.

${ }^{w}$ Western Regional Climate Center COOP Station number 459465, Yakima Air Terminal. 
weather station (Coupeville) is $28 \mathrm{~km}$ northeast of the orchard but only $\approx 80 \mathrm{~m}$ lower elevation than the orchard site. For the WSU NWREC site, the weather station is on the research center grounds, $700 \mathrm{~m}$ east of the orchard. For the Snowdrift Cider site, the weather station (East Wenatchee) is $1.2 \mathrm{~km}$ west of the orchard. For the Tieton Cider Works site, the weather station (Cowiche) is $8 \mathrm{~km}$ southeast of the orchard.

Statistical analysis. All data were subjected to analysis of variance using JMP software (version 12.0.0 for Windows; SAS Institute, Cary, NC). Log and reciprocal transformations were used to confirm data to the assumptions of normality and equality of variances; homogeneity of variances was assessed using Levene's test. Least squares fit tests were performed to evaluate the main two way and three way interactions. Orchard site was randomized within the main effect of region as variation among years was significant, providing for a final sample number of 32 (two regions $\times$ four cultivars $\times$ four years). Treatment means were compared using Fisher's least significant difference test with a $5 \%$ level of significance.

\section{Results}

Juice quality characteristics. There were no significant differences due to region and effects of region, cultivar, and year, and their

no significant interactions of region, cultivar, and/or year for any of the juice quality characteristics measured (Table 2). There were significant differences $(P<0.05)$ due to cultivar for all of the juice quality characteristics measured. 'Brown Snout', 'Dabinett', and 'Kingston Black' had higher SSC (14.11 \pm $0.52)$ than 'Yarlington Mill' (12.22 $\pm 0.49, P=$ 0.01; Table 3). 'Brown Snout', 'Dabinett', and 'Kingston Black' had higher SG (1.058 \pm $0.002)$ than 'Yarlington Mill' (1.049 \pm 0.002 , $P=0.002$; Table 4). 'Dabinett' had the highest $\mathrm{pH}(4.34 \pm 0.02)$ and lowest TA $(1.55 \pm 0.33)$, while 'Kingston Black' had the lowest $\mathrm{pH}$ $(3.56 \pm 0.03)$ and highest TA $(4.98 \pm 0.34$; Table 3). 'Yarlington Mill' had the highest tannin $(0.18 \pm 0.01)$ and 'Kingston Black' the lowest tannin $(0.10 \pm 0.01$; Table 4$)$. There were also significant differences due to year for SG and tannin $(P=0.01$ and $P=0.0005$, respectively). SG was higher on average in 2012,2014 , and $2015(1.058 \pm 0.002)$ than in $2013(1.050 \pm 0.002, P=0.01)$, while tannin was higher in $2012(0.20 \pm 0.01)$ than on average in $2013-15(0.13 \pm 0.01, P=0.0005$; Table 4).

Based on the results for TA and tannin, all four cultivars have a different classification as compared with historical records at LARS (recorded 1905-75; Table 5). 'Brown Snout' and 'Dabinett' are classified as sweet (acid $<0.45 \%$ ) in the current study but bittersweet at LARS, 'Kingston Black' is classified as

Table 2. Results from analysis of variance of the main factors "region," "cultivar," and "year," and their interactions for juice quality characteristics measured.

\begin{tabular}{lcccccc}
\hline & \multicolumn{5}{c}{$P$ value } \\
\cline { 2 - 7 } Characteristic & Region & Cultivar & Yr & Region $\times$ cultivar & Region $\times$ yr & Cultivar $\times$ yr \\
\hline SSC & 0.09 & 0.01 & 0.11 & 0.32 & 0.14 & 0.19 \\
SG & 0.11 & 0.002 & 0.01 & 0.27 & 0.12 & 0.39 \\
pH & 0.22 & $<0.0001$ & 0.06 & 0.14 & 0.08 & 0.11 \\
TA & 0.21 & $<0.0001$ & 0.27 & 0.36 & 0.15 & 0.44 \\
Tannin & 0.09 & $<0.0001$ & 0.0005 & 0.89 & 0.08 & 0.53 \\
\hline
\end{tabular}

$\mathrm{SSC}=$ soluble solids concentration; $\mathrm{SG}=$ specific gravity; $\mathrm{TA}=$ titratable acidity.

${ }^{\mathrm{z}}$ Main effects and their interactions were found to be significant at a 0.05 level of significance.

Table 3. Mean juice quality characteristics of four cider apple cultivars for those characteristics for which there was no difference due to region or year.

\begin{tabular}{lcccrr}
\hline & \multicolumn{5}{c}{ Cultivar } \\
\cline { 2 - 6 } Characteristic & Brown Snout & Dabinett & Kingston Black & Yarlington Mill & $P$ value $^{z}$ \\
\hline SSC $(\%)$ & $14.64 \mathrm{a}^{\mathrm{y}}$ & $14.04 \mathrm{a}$ & $13.64 \mathrm{a}$ & $12.22 \mathrm{~b}$ & 0.01 \\
pH & $3.94 \mathrm{c}$ & $4.34 \mathrm{a}$ & $3.56 \mathrm{~d}$ & $4.10 \mathrm{~b}$ & $<0.0001$ \\
TA $\left(\mathrm{g} \cdot \mathrm{L}^{-1}\right)^{\mathrm{x}}$ & $3.71 \mathrm{a}$ & $1.55 \mathrm{c}$ & $4.98 \mathrm{a}$ & $1.88 \mathrm{~b}$ & $<0.0001$ \\
\hline
\end{tabular}

$\mathrm{SSC}=$ soluble solids concentration; $\mathrm{TA}=$ titratable acidity.

${ }^{z}$ Significance of treatment effects were analyzed with analysis of variance using JMP software (version 12.0.1 for Windows; SAS Institute, Cary, NC).

yalues not connected by the same letter within the same row of each main effect are significantly different at a 0.05 level of significance according to Fisher's least significant difference test.

${ }^{\mathrm{x}}$ Malic acid equivalent. sharp (acid $>0.45 \%$ ) in the current study but bittersharp at LARS, and 'Yarlington Mill' is classified as sweet in the current study but bittersweet at LARS.

Climate data. Seasonal air temperatures differed between the two regions. During this study, northwest Washington experienced an average summer temperature of $16.0{ }^{\circ} \mathrm{C}$ and average winter temperature of $5.3{ }^{\circ} \mathrm{C}$ while central Washington experienced an average summer temperature of $22.1{ }^{\circ} \mathrm{C}$ and average winter temperature of $0.1{ }^{\circ} \mathrm{C}$. Temperature fluctuated throughout the year to a lesser extent in northwest Washington than in central Washington (Fig. 1). Average GDD from 2012 to 2015 were $25 \%$ lower in northwest Washington than in central Washington and average $\mathrm{CH}$ from 2012 to 2015 were $30 \%$ lower in northwest Washington than in central Washington (Table 6). Additionally, on average from 2012 to 2015 , GDD increased $11 \%$ in northwest Washington and $8 \%$ in central Washington, and $\mathrm{CH}$ decreased $14 \%$ in northwest Washington and $7 \%$ in central Washington (Table 6).

\section{Discussion}

All five of the juice quality characteristics that were measured in this study differed among the four cultivars as expected. 'Dabinett' had the lowest acid level followed by 'Yarlington Mill', 'Brown Snout' had a mediumlow level, and 'Kingston Black' had a mediumhigh level (Jolicoeur, 2013). Only 'Kingston Black' had an acid level greater than $0.45 \%$ and so was classified as sharp while the other three cultivars were classified as sweet. 'Kingston Black' had the lowest tannin level followed by 'Brown Snout', while 'Dabinett' and 'Yarlington Mill' had medium levels. However, none of the four cultivars had tannin levels greater than $0.20 \%$, and so none were classified as bitter in this study. In comparison with the historical records at LARS, the relative differences in juice quality characteristics between cultivars are similar, and the acid level of the juice of each of the four cultivars is similar, but the tannin levels are not. All four cultivars included in this study were classified as bitter at LARS. Similarly, 'Dabinett', 'Kingston Black', and 'Yarlington Mill' were classified as bitter in a previous study (2008-09) at WSU NWREC (Moulton et al., 2010). Unpublished data for all four cultivars collected at the New York Agricultural Experiment Station (NYAES) in Geneva, NY, showed similar results as the current study, that tannin levels were significantly lower than those recorded at LARS (LaBelle, 1980). The tannin data collected at NYAES was for finished cider not

Table 4. Mean juice quality characteristics for each year, and the four cider apple cultivars for those characteristics for which there was no difference due to region.

\begin{tabular}{|c|c|c|c|c|c|c|c|c|c|c|}
\hline \multirow[b]{2}{*}{ Characteristic } & \multicolumn{5}{|c|}{$\mathrm{Yr}$} & \multicolumn{5}{|c|}{ Cultivar } \\
\hline & 2012 & 2013 & 2014 & 2015 & $P$ value ${ }^{z}$ & Brown Snout & Dabinett & Kingston Black & Yarlington Mill & $P$ value \\
\hline$\overline{\mathrm{SG}}(\text { ratio })^{\mathrm{y}}$ & $1.056 \mathrm{a}^{\mathrm{x}}$ & $1.050 \mathrm{~b}$ & $1.059 \mathrm{a}$ & $1.058 \mathrm{a}$ & 0.01 & $1.060 \mathrm{a}$ & $1.058 \mathrm{a}$ & $1.056 \mathrm{a}$ & $1.049 \mathrm{~b}$ & 0.002 \\
\hline Tannin $(\%)^{\mathrm{w}}$ & $0.20 \mathrm{a}$ & $0.14 \mathrm{~b}$ & $0.13 \mathrm{~b}$ & $0.12 \mathrm{~b}$ & 0.0005 & $0.13 \mathrm{~b}$ & $0.17 \mathrm{ab}$ & $0.10 \mathrm{c}$ & $0.18 \mathrm{a}$ & $<0.0001$ \\
\hline
\end{tabular}

${ }^{\mathrm{z}}$ Significance of treatment effects were analyzed with analysis of variance using JMP software (version 12.0.1 for Windows; SAS Institute, Cary, NC).

${ }^{y}$ Specific gravity is the ratio of the density of the juice to the density of pure water.

'Values not connected by the same letter within the same row of each main effect are significantly different at a 0.05 level of significance according to Fisher's least significant difference test.

wTannic acid equivalent. 
Table 5. Classifications of four cider apple cultivars at Long Ashton Research Station (LARS; 1905-75; Barker, 1903) and in the current study (means for 2012-15).

\begin{tabular}{lccccccc}
\hline & \multicolumn{3}{c}{ LARS, England } & & \multicolumn{3}{c}{ Washington (current study) } \\
\cline { 2 - 4 } Cultivar & Acid (\%) & Tannin $(\%)^{y}$ & Class $^{\mathrm{x}}$ & & Acid (\%) & Tannin (\%) & Class \\
\hline Brown Snout & 0.24 & 0.24 & Bittersweet & & 0.37 & 0.13 & Sweet \\
Dabinett & 0.18 & 0.29 & Bittersweet & & 0.16 & 0.17 & Sweet \\
Kingston Black & 0.58 & 0.21 & Bittersharp & & 0.50 & 0.10 & Sharp \\
Yarlington Mill & 0.22 & 0.32 & Bittersweet & & 0.19 & 0.18 & Sweet \\
\hline
\end{tabular}

${ }^{\mathrm{z}}$ Malic acid equivalent.

${ }^{\mathrm{y}}$ Tannic acid equivalent.

${ }^{\mathrm{x}}$ Bittersweet $(>0.20$ tannin, $<0.45$ acid $)$, bittersharp ( $>0.20$ tannin, $>0.45$ acid $)$, sharp $(<0.20 \operatorname{tannin},>0.45$ acid), sweet ( $<0.20$ tannin, $<0.45$ acid $)$.

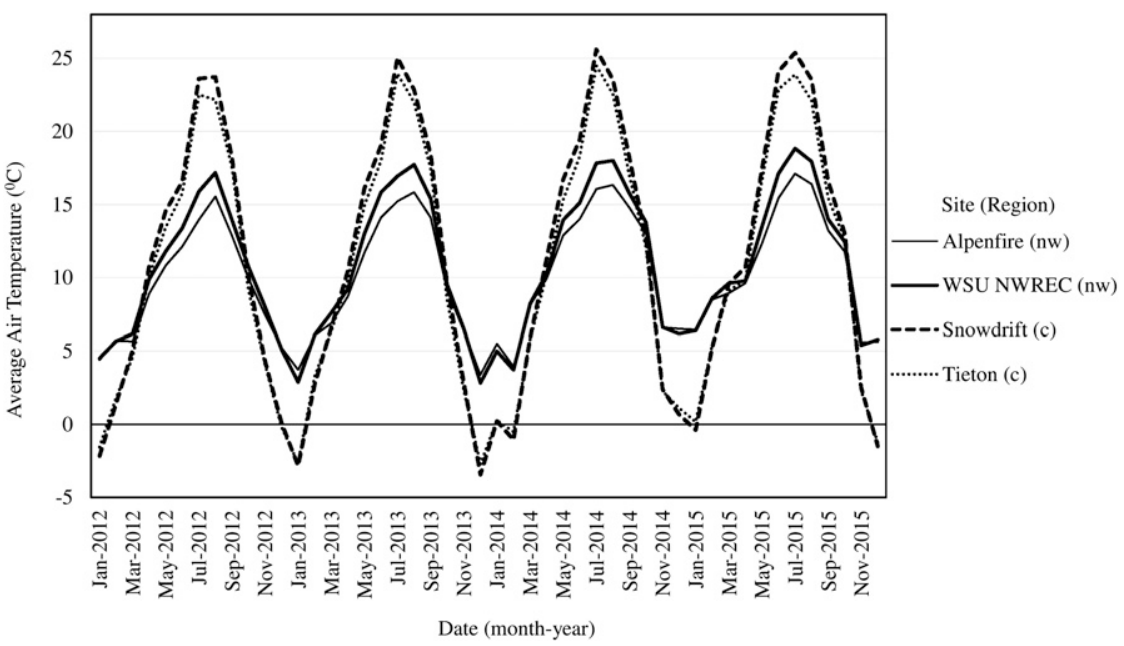

Fig. 1. Annual average air temperature at four cider orchards [Alpenfire Cider, Washington State University Northwestern Washington Research and Extension Center (WSU NWREC), Snowdrift Cider Co., and Tieton Cider Works] in northwest (nw) and central (c) Washington, respectively, from 2012 to 2015.

Table 6. Annual GDD and CHx at the four cider orchards in northwest and central Washington, from 2012 to 2015 .

\begin{tabular}{|c|c|c|c|c|}
\hline \multirow[b]{2}{*}{$\mathrm{GDD}^{\mathrm{z}}$} & \multicolumn{2}{|c|}{ Northwest Washington } & \multicolumn{2}{|c|}{ Central Washington } \\
\hline & $\overline{\text { Alpenfire } \text { Cider }^{y}}$ & WSU NWREC & Snowdrift Cider Co. ${ }^{\mathrm{w}}$ & Tieton Cider Works \\
\hline 2012 & 2,968 & 3,228 & 4,103 & 3,641 \\
\hline 2013 & 3,169 & 3,431 & 4,527 & 4,082 \\
\hline 2014 & 3,451 & 3,678 & 4,817 & 4,409 \\
\hline 2015 & 4,160 & 4,267 & 5,119 & 4,661 \\
\hline Mean & \multicolumn{2}{|c|}{3,544} & \multicolumn{2}{|c|}{4,420} \\
\hline Mean change (\%) & \multicolumn{2}{|c|}{11} & \multicolumn{2}{|c|}{8.10} \\
\hline \multicolumn{5}{|l|}{$\mathrm{CH}^{\mathrm{u}}$} \\
\hline 2012 & 3,345 & 2,905 & 3,711 & 3,742 \\
\hline 2013 & 3,108 & 2,751 & 3,476 & 3,587 \\
\hline 2014 & 2,730 & 2,590 & 3,481 & 3,575 \\
\hline 2015 & 2,005 & 1,868 & 2,965 & 3,054 \\
\hline Mean & \multicolumn{2}{|c|}{2,663} & \multicolumn{2}{|c|}{3,449} \\
\hline Mean change (\%) & \multicolumn{2}{|c|}{-14} & \multicolumn{2}{|c|}{-670} \\
\hline
\end{tabular}

GDD = growing degree days; $\mathrm{CH}=$ chilling hours experienced; WSU NWREC $=$ Washington State University Northwestern Washington Research and Extension Center.

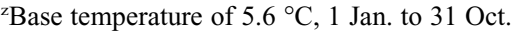

${ }^{\mathrm{y}} \mathrm{AgWeatherNet}$, Coupeville station.

${ }^{x} \mathrm{AgWeatherNet,}$ WSU NWREC station.

${ }^{w} \mathrm{AgWeatherNet}$, East Wenatchee station.

${ }^{\mathrm{A}} \mathrm{AgWeatherNet,} \mathrm{Cowiche} \mathrm{station.}$

"Base temperature of $7.2^{\circ} \mathrm{C}, 1$ Oct. to 31 May.

apple juice, but according to Williams et al. (1977), there are generally no significant differences between the tannin of apple juice and finished cider. Lea (2008) hypothesizes that the almost two to one difference between the NYAES and LARS data are attributable to differences in cultural practices between
In contrast, the data obtained in the current study were collected from cider cultivars predominantly grown on dwarfing rootstocks that were relatively intensively managed. In northwest and central Washington, the orchards were drip or microsprinkler irrigated and foliarly or ground fertilized (predominantly nitrogen) to avoid deficiencies. The trees sampled for the LARS data were most likely more stressed than the trees sampled in the current study, and this difference could explain the lower tannin levels in Washington as greater stress has been correlated with greater fruit tannin content (Lea and Beech, 1978). With lower levels of tannin, Washington cider makers may need to use a larger proportion of cider apples than is used by English cider makers to achieve the same level of bitterness and astringency.

None of the five juice quality characteristics measured in this study differed between the two regions in Washington. That is, on average, 'Brown Snout', 'Dabinett', 'Kingston Black', and 'Yarlington Mill' had the same general sweetness, acidity, and bitterness whether they were grown at the two northwest Washington locations or the two central Washington locations used in this study. Two of the characteristics, SG and tannin, did differ due to year. While growers in the region commonly cold store fruit for up to several months before pressing, cold storage can increase SG (Miles and King, 2014), and may account for the variability in SG in this study. GDD, which influence fruit quality, and $\mathrm{CH}$, which influence fruit set, varied from year to year in this study; specifically, GDD increased and $\mathrm{CH}$ decreased progressively each year in both regions. The progressive change in climate experienced from 2012 to 2015 could explain the drop in tannin (and therefore decline in bitterness) among all cultivars as increased temperature during the prior fall (lesser $\mathrm{CH}$ ) and from bloom to the onset of ripening (increased GDD) have been negatively correlated with concentrations of anthocyanins, tannins, and iron-reactive polyphenols in wine grapes (Nicholas et al., 2011). On the basis of this same relationship, it would be expected that tannin would have been lower in northwest Washington than central Washington, and that 'Brown Snout' and 'Kingston Black' would have been classified as bitter in central Washington. However, the relatively high levels of light interception experienced in the central Washington orchards could have canceled out the gains in tannin content from the increasing GDD as high sun exposure has been negatively correlated with tannin concentration and extractability during ripening in wine grapes (Downey et al., 2004; Nicholas et al., 2011). Utilization of different tree training systems among the four orchards in this study confounds a discussion of light interception and juice quality as apple fruit quality (in terms of size and chemical characteristics) has been established to vary with training system (Hassan et al., 2010; Licznar-Malańczuk, 2006). 
Unpublished data from Lea (2016) in Herefordshire, England, found that tannin levels in 'Dabinett' under the same fertilizer regime for 10 years exhibited significant annual variation, with a $\mathrm{CV}$ of $25 \%$, similar to findings in the present study (Lea, 2016). Characterization by Valois et al. (2006) of 31 cider apple cultivars in New York from 2002 to 2003 found substantial variation in tannin content from year to year. Analysis of cider apple juice tannin in terms of polyphenolic composition and size should be performed to more fully understand the impact of this juice quality characteristic and the influences of environmental variables. The impact of modern training systems, including rootstocks, on the juice quality of cider apples should also be considered for future work as there does not appear to be uniformity in production systems across regions as evidenced from this study.

\section{Conclusions}

In Washington, cider apple cultivation originated in the northwest region that has a similar climate to regions in Europe where cider apple production has its historic roots. However, cider apples are increasingly cultivated in central Washington, as the production, processing, and marketing infrastructure that are in place in that region for the dessert apple industry provide the potential for significant growth in the cider apple industry. This study indicates that juice quality was similar for four popular cider apple cultivars produced in northwest Washington and in central Washington. Furthermore, in this study there was year-to-year variability of SG and tannin, generally considered the most important characteristics of cider apples, supporting the importance of testing fruit and juice quality every growing season and before each fermentation. Future research should investigate cider apple juice tannin using more current methods (e. g., high-performance liquid chromatography and ultra-performance liquid chromatography-tandem mass spectrometry) to allow for a better understanding of tannin variability among regions and years. Research is also needed to measure cider apple juice quality characteristics in response to different tree training systems, environmental conditions, and nutrient and irrigation stresses in modern orchards in the United States. These future studies will provide growers and cider makers with more robust guidance in making cider apple cultivar purchasing and planting decisions for their region.

\section{Literature Cited}

AgWeatherNet. 2015. Weather data: Climate summary. Washington State Univ. 21 Mar. 2016. $<$ http://weather.wsu.edu/?p=96350>.

Alcohol and Tobacco Tax and Trade Bureau (TTB). 2016. Cider statistics CY 2007-2015. TTB, Washington, DC.

Alcohol and Tobacco Tax and Trade Bureau (TTB). 2015. Code of federal regulations, 27 CFR Part 24. U.S. Dept. Treasury, Washington, DC. 17 Mar. 2016.

Alwood, W.B. 1903. A study of cider making. U.S. Dept. Agr., Bur. Chem. Bul. 71.

Barker, B.T.P. 1903. Classification of cider apples. Natl. Fruit Cider Inst., Long Ashton Res. Sta., Bristol, UK.

Barker, B.T.P. 1911. Cider-making. J. Royal Hort. Soc. 36:570-573.

Barker, B.T.P. and L.F. Burroughs. 1953. Cider apple varieties then and now: A survey of vintage-quality trials, p. 45-55. In: T. Wallace and R.W. Marsh (eds.). Science and fruit. Univ. Bristol, Bristol, UK.

Buell, J.S. 1869. Cider makers' manual. Haas and Kelley, Buffalo, NY.

Chu, C.I.G. and K.R. Wilson. 2000. Evaluating maturity of 'McIntosh' and 'Red Delicious' apples. Ontario Ministry Agr. Food Rural Affairs, Publ. Order No. 00-025. 22 Mar. 2016. <http://www.omafra.gov.on.ca/english/ crops/facts/00-025.htm>.

Downey, M.O., J.S. Harvey, and S.P. Robinson. 2004. The effect of bunch shading on berry development and flavonoid accumulation in Shiraz grapes. Austral. J. Grape Wine Res. 10:55-73.

Grappadelli, L.C. 2003. Light relations, p. 208210. In: D.C. Ferree and I.J. Warrington (eds.). Apples: Botany, production, and uses. Ohio State Univ., Columbus, $\mathrm{OH}$.

Hassan, H.S.A., S.M.A. Sarrwy, E.A.M. Mostafa, and D.M. Ahmed. 2010. Influence of training systems on leaf mineral contents, growth, yield and fruit quality of "Anna" apple trees. J. Agr. Biol. Sci. 6:443-448.

Jolicoeur, C. 2013. The new cider maker's handbook: A comprehensive guide for craft producers. Chelsea Green Publishing, White River Junction, VT.

Khanizadeh, S., Y. Groleau, I. Ali, D. Guarino, and R. Dumois. 2000. New hardy apple scab resistant selections for cider and juice production. Acta Hort. 538:697-702.

Labelle, R.L. 1980. Apple cultivars tested as naturally fermented cider at Geneva. State Agr. Expt. Sta., Memo, Geneva, New York.

Lau, O.L. 1988. Harvest indices, dessert quality, and storability of 'Jonagold' apples in air and controlled atmosphere storage. J. Amer. Soc. Hort. Sci. 113:564-569.

Lea, A. 2008. Craft cider making. 3rd ed. The Good Life Press, Preston, UK.

Lea, A. 2016. Tannin variation in the orchard. 18 July 2016. <http://www.cider.org.uk/tannin.html>.

Lea, A.G.H. and F.W. Beech. 1978. The phenolics of ciders: Effects of cultural conditions. J. Sci. Food Agr. 29:493-496.

Licznar-Malańczuk, M. 2006. Training system and fruit quality in the apple cultivar 'Jonagold'. J. Fruit Ornamental Plant Res. 14:213-218.
Lowenthal, J. 1877. Uber die bestimmung des gerbstoffs. Z. Anal. Chem. 16:33-48.

Merwin, I.A., S. Valois, and O. Padilla-Zakour. 2008. Cider apples and cider-making techniques in Europe and North America. Hort Reviews 34:365-414.

Miles, C.A. and J. King. 2014. Yield, labor, and fruit and juice quality characteristics of machine and hand-harvested 'Brown Snout' specialty cider apple. HortTechnology 24 : 519-526.

Miller, S.S., R.W. McNew, B.H. Barritt, L. Berkett, S.K. Brown, J.A. Cline, J.M. Clements, W.P. Cowgill, R.M. Crassweller, M.E. Garcia, D.W. Greene, G.M. Greene, C.R. Hampson, I. Merwin, D.D. Miller, R.E. Moran, C.R. Rom, T.R. Roper, J.R. Schupp, and E. Stover. 2005. Effect of cultivar and site on fruit quality as demonstrated by the NE-183 regional project on apple cultivars. HortTechnology 15:886-895.

Mitchell, P. 2015. Cider \& perry production: Principles \& practice course notes. Mitchell F\&D Limited, Newent, UK.

Moulton, G.A., C.A. Miles, J. King, and A. Zimmerman. 2010. Hard cider production \& orchard management in the Pacific Northwest. PNW621, Washington State Univ., Pullman, WA.

Nicholas, K.A., M.A. Matthews, D.B. Lobell, N.H. Willits, and C.B. Field. 2011. Effect of vineyard-scale climate variability on Pinot noir phenolic composition. Agr. For. Meteorol. 151:1556-1567.

Northwest Cider Association. 2015. Northwest cider association members. 10 Apr. 2014. $<$ http://www.nwcider.com/washington-cidermakers $/>$.

Pollard, A. 1953. Factors affecting the quality of cider, p. 56-67. In: T. Wallace and R.W. Marsh (eds.). Science and fruit. Univ. Bristol, Bristol, UK.

Robinson, T.L., E.J. Seeley, and B.H. Barritt. 1983. Effect of light environment and spur age on 'Delicious' apple fruit size and quality. J. Amer. Soc. Hort. Sci. 108:855-861.

The Cyder Market. 2015. Domestic cider: Washington cidermakers. 9 Mar. 2016. <https:// www.cydermarket.com/washington.html>.

Trowbridge, J.M. 1917. The cider makers' hand book: A complete guide for making and keeping pure cider. Orange Judd, New York.

U.S. Department of Agriculture. 2013. Web soil survey. U.S. Dept. Agr. 17 Sept. 2013. <http:// websoilsurvey.nrcs.usda.gov>.

Valois, S., I.A. Merwin, and O.I. Padilla-Zakour. 2006. Characterization of fermented cider apple cultivars grown in upstate New York. J. Amer. Pomol. Soc. 60:113-128.

Western Regional Climate Center. 2010. Climate summary: Monthly tabular data. 20 Mar. 2016. $<$ http://www.wrcc.dri.edu/cgi-bin/cliMAIN.pl? wa6678>.

Williams, A.A., A.G.H. Lea, and C.F. Timberlake. 1977. Measurement of flavor quality in apples, apple juices, and fermented ciders, p. 71-88. In: R.A. Scanlan (ed.). Flavor quality: Objective measurement. Amer. Chem. Soc., Washington, DC.

Williams, R.R. 1987. Bulmer's pomona. Fourth Estate Ltd., London, UK. 